\title{
INHIBITION BY NEOMYCIN OF POLYPHOSPHOINOSITIDE TURNOVER IN SUBCELLULAR FRACTIONS OF GUINEA-PIG CEREBRAL CORTEX IN VITRO
}

\author{
J. SCHACHT \\ Kresge Hearing Research Institute and Department of Biological Chemistry, \\ University of Michigan, Ann Arbor, MI 48109, U.S.A.
}

(Received 13 April 1976. Accepted 17 May 1976)

\begin{abstract}
The addition of $10^{-5} \mathrm{M}$ to $10^{-3} \mathrm{M}$ neomycin to incubations of subcellular fractions of guineapig cerebral cortex increased the labelling of phosphatidylinositol phosphate and decreased the labelling of phosphatidylinositol diphosphate by $\left[\gamma^{32} \mathrm{P}\right] \mathrm{ATP}$. The effect was observed in all subcellular fractions tested and depended on the cationic form of the antibiotic. Similar effects on lipid labelling were exerted by related aminoglycosidic antibiotics, by neamine, spermine and poly-L-lysine. Other neomycin fragments, antibiotics, local anesthetics or small polyamines were ineffective. Neomycin also inhibited the enzymatic hydrolysis of ${ }^{32} \mathrm{P}$-polyphosphoinositides. The addition of the drug to aqueous dispersions of these lipids increased the turbidity and lowered the $\mathrm{pH}$ of the suspensions. It is suggested that the effects of neomycin on polyphosphoinositide metabolism result from the formation of an ionic complex between the lipids and the antibiotic.
\end{abstract}

AMINOGLYCOSIDE antibiotics - neomycin, streptomycin, and related compounds - are potent antibacterial agents, but also exert toxic actions on eukaryotic cells. These actions include block of neuromuscular and ganglionic transmission (PITtinger \& Adamson, 1972), nephrotoxicity, and, most prominently, ototoxicity in the cochlea and the vestibular system (HawKINS, 1970).

We have recently demonstrated (SCHACHT, 1974; ORSULAKOVA et al., 1976) that the incorporation of ${ }^{32} \mathrm{P}_{\mathrm{i}}$ into polyphosphoinositides is altered in inner ear tissues of guinea pigs receiving chronic ototoxic doses of neomycin. In acute experiments with cochlear perfusions we have shown that the change of polyphosphoinositide labelling followed the same dose response as the decrease of cochlear microphonic potential (Nutrall et al., 1975). Although a physiological role for the polyphosphoinositides (phosphatidylinositol phosphate and phosphatidylinositol diphosphate) has not yet been established, there are strong indications that they are involved in the control of membrane permeability in bioelectric events (MiCHELL, 1975). Of all tissues, brain has the highest content of polyphosphoinositides (HAUSER \& EICHBERG, 1973) and provides a convenient system to study their metabolism. We therefore investigated the mechanism of neomycin action on the turnover of phosphatidylinositol phosphate and phosphatidylinositol diphosphate in subcellular fractions of guinea-pig cerebral cortex in vitro.

Abbreviations used in tables and figures: PhA, phosphatidic acid (1,2-diacyl-sn-glycero-3-phosphate); PhI, PhIP, $\mathrm{PhIP}_{2}$. phosphatidylinositol, phosphate. diphosphate; Nm, Neomycin B.

\section{MATERIALS AND METHODS}

Cerebral cortex from albino guinea-pigs was homogenized in $0.32 \mathrm{M}$-sucrose in a Teflon-glass homogenizer to yield a $10 \%$ homogenate $(\mathrm{w} / \mathrm{v})$. This was centrifuged for $10 \mathrm{~min}$ at $1000 \mathrm{~g}$ and washed once. The combined supernatant fractions were centrifuged for $20 \mathrm{~min}$ at $13,000 \mathrm{~g}$ to yield a crude nerve ending-mitochondrial pellet and a supernatant fraction containing cytosol and microsomes. The nerve ending-mitochondrial pellet was suspended in $30 \mathrm{ml}$ of $0.32 \mathrm{M}$-sucrose, and was layered over three tubes of a discontinuous gradient consisting of $13 \mathrm{ml}$ each of 0.8 - and $1.2 \mathrm{M}$-sucrose, which was centrifuged in an SW 27 rotor for $120 \mathrm{~min}$ at $62,000 \mathrm{~g}$. Fractions collected at the interfaces were a myelin-rich fraction over $0.8 \mathrm{M}$-sucrose, a nerve ending-rich fraction over $1.2 \mathrm{M}$-sucrose and a pellet containing mitochondria. The fractions were pelleted by centrifuging for $30 \mathrm{~min}$ at $100,000 \mathrm{~g}$. Each pellet was suspended in $0.16 \mathrm{M}$-sucrose $/ 5 \mathrm{mM}$-Tris- $\mathrm{Cl}(\mathrm{pH} \mathrm{7.4)}$ and frozen twice in a dry-ice-acetone bath and thawed.

For lipid labelling, incubations were performed at $37^{\circ} \mathrm{C}$ in air with shaking. The fractions were incubated for $15 \mathrm{~min}$ with $40 \mathrm{~mm}$-Tris- $\mathrm{Cl}$ (pH 7.4) and $10 \mathrm{~mm}$-dithioerythritol, in the presence or absence of drugs; all in a volume of $0.25 \mathrm{ml}$. Then were added (final concentrations) $80 \mathrm{~mm}-$ Tris-Cl (pH 7.4), $20 \mathrm{~mm}-\mathrm{MgCl}_{2}, 0.2 \mathrm{~mm}-\mathrm{EDTA}$, and $4 \mathrm{mM}-\left[\gamma^{32} \mathrm{P}\right] \mathrm{ATP}$; final volume, $0.5 \mathrm{ml}$. The incubations were terminated by the addition of $1.5 \mathrm{ml}$ of chloroformmethanol $(1: 2, \mathrm{v} / \mathrm{v})$. After addition of $0.5 \mathrm{ml} 2.4 \mathrm{~N}-\mathrm{HCl}$ and $1.0 \mathrm{ml}$ of chloroform, mixing and centrifugation, the lower phase was collected and the upper phase was reextracted with $1.0 \mathrm{ml}$ of chloroform. Samples of the remaining upper phase were analyzed for $\left[{ }^{32} \mathrm{P}\right] \mathrm{ATP}$ (HuANG, 1970). The combined lower phases were washed with $2.0 \mathrm{ml}$ of methanol- $0.5 \mathrm{~N}-\mathrm{HCl}(2: 3, \mathrm{v} / \mathrm{v})$ and the upper layer was discarded. Maintainance of high acidity in the upper phase during extraction and washing was necessary for complete recovery of polyphosphoinositides. Portions of the lower phase were removed for the determination of total 
lipid- ${ }^{32} \mathrm{P}$, the rest was dried under $\mathrm{N}_{2}$. For TLC the lipids were taken up in a small volume of chloroform-methanolconc. $\mathrm{HCl}(6: 3: 0.1$, by vol) and applied to TLC plates 'Silicagel 60' (E. Merck). Routinely. plates were developed in chloroform methanol-aqueous conc. $\mathrm{NH}_{3}-\mathrm{H}_{2} \mathrm{O}$ (45:45:3.5:11, by vol) which resulted in good separation of phosphatidylinositol phosphate. phosphatidylinositol diphosphate and phosphatidic acid. ${ }^{32}$ P-lipids were located by autoradiography, scraped and counted by liquid scintillation. Lipid standards for identification were commercial (AvaNTI. Birmingham. AL) or, in the case of polyphosphoinositides, were prepared according to HENDRICKSON \& BALLOU (1964).

Hydrolysis of phospholipids was studied with previously extracted ${ }^{32} \mathrm{P}$-labelled lipids. The lipid extract was dried under $\mathrm{N}_{2}$ and suspended in $40 \mathrm{~mm}$-Tris-Cl $(\mathrm{pH} 7.4)$ with a Polytron PT 10-35 (Brinkman Instr.). Portions of this suspension were incubated at $37^{\circ} \mathrm{C}$ with the nerve ending fraction in (final concentrations) $80 \mathrm{~mm}-\mathrm{Tris}-\mathrm{Cl} \mathrm{pH} 7.4$. $1 \mathrm{~mm}-\mathrm{NaF}$, and $1 \mathrm{~mm}-\mathrm{MgCl}_{2}$, in a total vol of $0.5 \mathrm{ml}$. Incubations were terminated and lipids extracted as above.

For studies of physicochemical interactions between neomycin and the polyphosphoinositides. the lipids were prepared by chromatography on DEAE-cellulose (HENDRICKSON \& BALLOU, 1964) from bovine brain obtained from a local slaughterhouse. The composition of the lipid fraction used in these experiments was estimated after TLC to be $80 \%$ phosphatidylinositol diphosphate and $20^{\circ}$ o phosphatidylinositol phosphate with only traces of other phospholipids. Dispersions of this lipid fraction in 20 mM-Tris- $\mathrm{Cl}$ ( $\mathrm{pH} 7.4$ ) were mixed with increasing concentrations of neomycin and turbidity was determined in a spectrophotometer at $520 \mathrm{~nm}$ (FEINSTEIN, 1964) after a stable absorbance was reached. Dilutions of the lipid suspension with water served as blanks. Neomycin does not absorb at $520 \mathrm{~nm}$. For $\mathrm{pH}$ titrations with neomycin, the lipids were suspended in water and the suspension as well as the drug were adjusted with $\mathrm{HCl}$ or $\mathrm{NaOH}$ to $\mathrm{pH} 6.10 \pm 0.03$. Changes of $\mathrm{pH}$ of the lipid dispersion upon addition of neomycin were monitored with a $\mathrm{pH}$ meter.

$\left[\gamma^{3}{ }^{32} \mathrm{P}\right]$ ATP was prepared enzymatically (SCHENDEL \& WelLS, 1973). Lipid phosphorus (AMES \& DuBIN, 1960) and protein (Lowry et al.. 1951) were determined spectrophotometrically. Neomycin B sulfate and fragments were a gift from The Upjohn Co. (Kalamazoo. MI). Radioactive materials were purchased from New England Nuclear (Boston. MA).

Data presented are generally averages of at least duplicate determinations with variability less than $10^{\circ}{ }_{0}$.

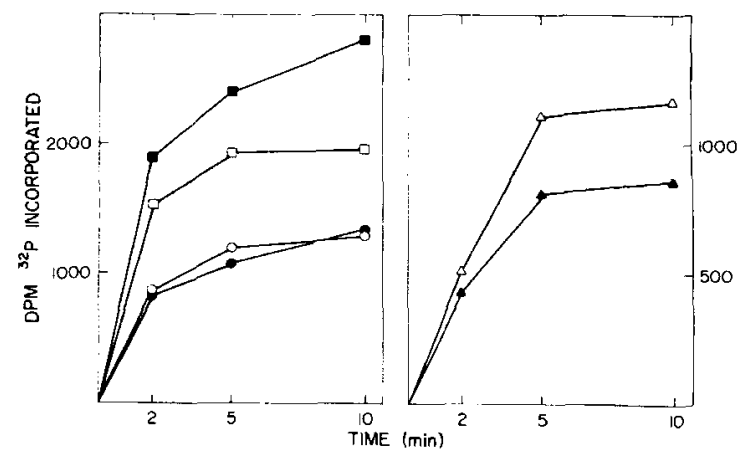

Fig. 1. Time course of ${ }^{32} \mathrm{P}$-incorporation into phospholipids. A nerve ending fraction $(0.8 \mathrm{mg}$ protein) was incubated as described in 'Methods' with $10 \mu \mathrm{Ci}{ }^{32} \mathrm{P}$-ATP. ○ $\bigcirc$ phosphatidic acid; $\square \longrightarrow \square$ phosphatidylinositol phosphate: $\triangle-\triangle$ phosphatidylinositol diphosphate. Open symbols: controls; closed symbols: $10^{-4} \mathbf{M}^{-}$ neomycin.

\section{RESULTS}

\section{Labelling of subcellular fractions}

Fractions obtained by differential and density gradient centrifugation were incubated with $\left[\gamma_{-}{ }^{32}\right.$ P $]$ ATP in the absence or presence of $10^{-4} \mathrm{M}$-neomycin (Table 1). Phosphatidic acid, phosphatidylinositol phosphate and phosphatidylinositol diphosphate were the only significantly labelled lipids, as confirmed by two dimensional TLC (EICHBERG et al., 1973). The nerve ending fraction showed the highest activity of incorporation per $\mathrm{mg}$ protein. The addition of neomycin increased phosphatidylinositol phosphate labelling in all fractions 1.5- to 2-fold, whereas phosphatidylinositol diphosphate labelling was generally decreased. Radioactivity in phosphatidic acid did not seem to be affected with the possible exception of the myelin-rich fraction.

The time course of labelling (Fig. 1) showed linearity of ${ }^{32} \mathrm{P}$-incorporation for somewhat less than $5 \mathrm{~min}$. The effect of $10^{-4} \mathrm{M}$-neomycin on polyphosphoinositide labelling was evident at all times, while no influence was observed on phosphatidic acid labelling.

\section{Effect of neomycin}

The changes of ${ }^{32} \mathrm{P}$-incorporation into the polyphosphoinositides depend on the concentration of

TABle 1. Labelling of PHOSPHOLIPIDS IN SUbCellular fractions

\begin{tabular}{|c|c|c|c|c|c|c|c|}
\hline \multirow[b]{2}{*}{ Fraction } & \multirow{2}{*}{$\begin{array}{l}\text { mg protein } \\
\text { per incubation }\end{array}$} & \multicolumn{2}{|c|}{ PhIP } & \multicolumn{2}{|c|}{$\mathrm{PhIP}_{2}$} & \multicolumn{2}{|c|}{$\mathrm{PhA}$} \\
\hline & & Control & $+\mathrm{Nm}$ & Control & $+\mathrm{Nm}$ & Control & $+\mathrm{Nm}$ \\
\hline & & \multicolumn{6}{|c|}{ d.p.m. incorporated } \\
\hline Mitochondria & 0.7 & 782 & 1364 & 186 & 247 & 322 & 385 \\
\hline Nerve endings & 0.4 & 2900 & 4677 & 1160 & 596 & 695 & 588 \\
\hline Myelin & 0.2 & 811 & 1210 & 322 & 233 & 352 & 192 \\
\hline $13,000 \mathrm{~g}$ supernatant & 1.0 & 2490 & 3740 & 1530 & 1375 & 3178 & 3175 \\
\hline
\end{tabular}

The fractions were incubated with $10 \mu \mathrm{Ci}{ }^{32} \mathrm{P}-\mathrm{ATP}$ for $5 \mathrm{~min}$ as described in 'Methods: Neomycin was $10^{-4} \mathrm{M}$. 


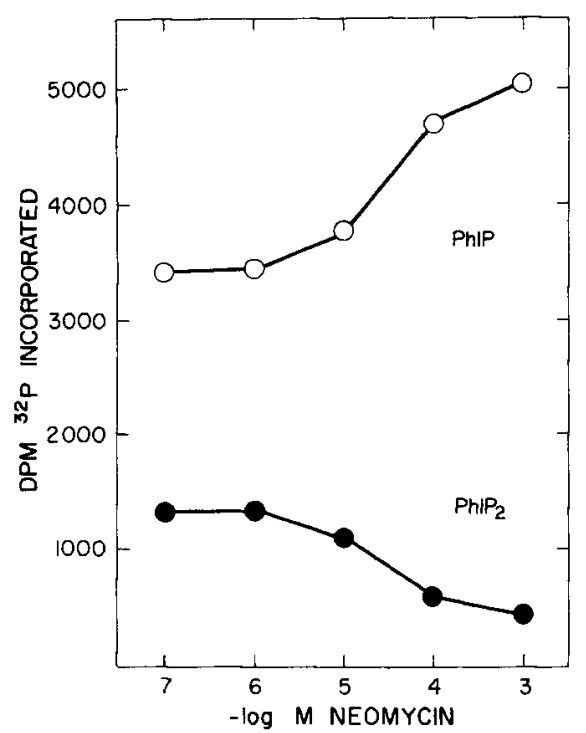

FIG. 2. Effect of neomycin concentration on labelling of polyphosphoinositides. A nerve ending fraction $(0.6 \mathrm{mg}$ protein) was incubated as described in 'Methods' with $12 \mu \mathrm{Ci}{ }^{32} \mathrm{P}$-ATP for $5 \mathrm{~min}$.

neomycin (Fig. 2). Both the decrease in ${ }^{32}$ P-phosphatidylinositol diphosphate and the increase in ${ }^{32} \mathrm{P}$-phosphatidylinositol phosphate are clearly evident at $10^{-4} \mathrm{M}$-neomycin and in some cases-as in the experiment presented-small effects could be observed at $10^{-5} \mathrm{M}$ drug.

The incubation medium was similar to that of $\mathrm{KAI}_{\mathrm{AI}}$ et al. (1968) and had been modified to promote the highest rate of ${ }^{32} \mathrm{P}$-incorporation into the polyphosphoinositides. Variation of its composition did not significantly influence the effect of neomycin except when changes in the magnesium concentration (Table 2) or in $\mathrm{pH}$ (Fig. 3) were made. With increasing $\mathrm{Mg}^{2+}$, the basal rate of labelling of phosphatidylinositol phosphate was enhanced about six-fold while the relative effect of neomycin (percentage stimulation) was decreased. Phosphatidylinositol diphosphate also responded to $\mathrm{Mg}^{2+}$, and neomycin which inhibited its labelling at higher $\mathrm{Mg}^{2+}$ slightly stimulated it at $1 \mathrm{mM}-\mathrm{MgCl}_{2}$.

A rather broad $\mathrm{pH}$ optimum is observed for the ${ }^{32} \mathrm{P}$-incorporation into phosphatidylinositol phos-

TABLE 2. EfFECt OF $\mathrm{MgCl}_{2}$ ON NEOMYCIN Stimulated POLYPHOSPHOINOSITIDE LABELLING

\begin{tabular}{rrrcr}
\hline & \multicolumn{2}{c}{ PhIP } & \multicolumn{2}{c}{$\mathrm{PhIP}_{2}$} \\
$\mathrm{MgCl}_{2}$ & Control & $+\mathrm{Nm}$ & Control & $+\mathrm{Nm}$ \\
\hline \multicolumn{4}{c}{ d.p.m. incorporated } \\
$1 \mathrm{mM}$ & 736 & 2250 & 745 & 930 \\
$5 \mathrm{~mm}$ & 1787 & 3895 & 1932 & 1655 \\
$20 \mathrm{mM}$ & 4470 & 6520 & 2180 & 1560 \\
\hline
\end{tabular}

A nerve ending fraction ( $2 \mathrm{mg}$ protein) was incubated as described in 'Methods' with $\mathrm{MgCl}_{2}$ as indicated and $18 \mu \mathrm{Ci}{ }^{32} \mathrm{P}$-ATP for $5 \mathrm{~min}$. Neomycin was $2 \times 10^{-4} \mathrm{M}$.

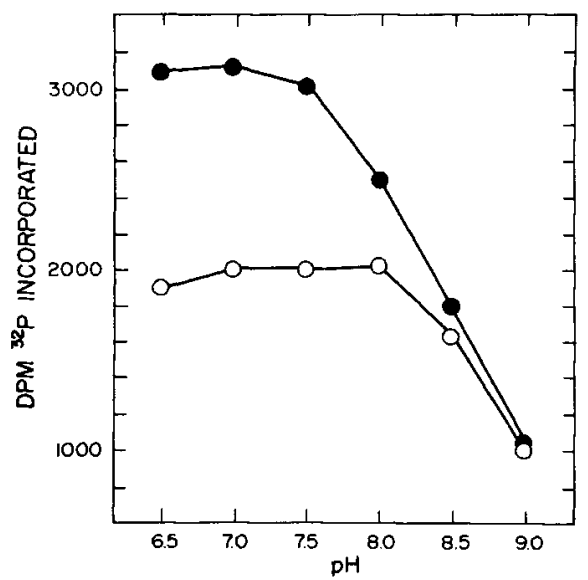

FIG. 3. Effect of $\mathrm{pH}$ on neomycin stimulation of phosphatidylinositol phosphate labelling. A nerve ending fraction ( $2 \mathrm{mg}$ protein) was incubated with $7 \mu \mathrm{Ci}{ }^{32} \mathrm{P}$-ATP for $5 \mathrm{~min}$ as described in 'Methods' except that $\mathrm{MgCl}_{2}$ was $5 \mathrm{~mm}$ and Tris maleate was substituted for Tris-Cl. Open sym-

bols: controls; closed symbols: $10^{-4} \mathrm{M}$-neomycin.

phate (and for diphosphate, not shown). At $\mathrm{pH} 8.5$ labelling proceeds at about $80 \%$ and at $\mathrm{pH} 9$ at $50 \%$ of the maximal rate. In contrast, stimulation by neomycin is essentially abolished at $\mathrm{pH} 8.5$ and 9.0 .

\section{Comparison with other drugs}

The action of neomycin was compared with that of a number of other drugs (Table 3).

Tobramycin, gentamicin and kanamycin, which are desoxystreptamine antibiotics, as is neomycin. stimulated labelling of phosphatidylinositol phosphate. Streptomycin an aminoglycoside of the streptidine group decreased ${ }^{32} \mathrm{P}$-phosphatidylinositol diphosphate (Table 3, Exp. A). Of the neomycin fragments (Exp. B) only neamine was found to increase phosphatidylinositol labelling. The magnitude was less than with the intact antibiotic, but a stimulation was consistently observed in a number of experiments. Other inhibitors of bacterial protein synthesis, such as puromycin and clindamycin or local anaesthetics (Exp. C) were ineffective. The polyamine spermine, however, and the polyamino acid poly-L-lysine (Exp. D) altered polyphosphoinositide labelling similarly to neomycin.

In most of these experiments, $\left[\gamma^{32} \mathrm{P}\right] \mathrm{ATP}$ was measured at the end of the incubation time. About $30 \%$ of the intially added ATP was usually recovered, and $10^{-4} \mathrm{M}$-neomycin decreased this amount by about $10 \%$ (i.e. $25-27 \%$ recovered). The increased hydrolysis of ATP in the presence of neomycin may account for some of the drug effect on phosphatidic acid labelling. A consistent decrease of $\left[{ }^{32} \mathrm{P}\right]$ phosphatidate could only be observed at higher drug concentrations. In contrast to neomycin, poly-L-lysine inhibited the hydrolysis of ATP slightly (about $15^{\circ}$ ). Other drugs did not show effects that exceeded $10 \%$. 
Table 3. EFFect of variols DRLgS ON tHe labelling OF PHOSPHOLIPIDS

\begin{tabular}{llrrr}
\hline & \multicolumn{1}{c}{ Drug $\left(10^{-1}\right.$ M) } & PhIP & PhIP & PhA \\
\hline \multirow{3}{*}{ Exp. A } & None & d.p.m. & incorporated \\
& Neomycin & 5963 & 1689 & 3068 \\
& Tobramycin & 8899 & 1196 & 2992 \\
& Gentamicin & 8327 & 1540 & 3092 \\
& Kanamycin & 8098 & 1670 & 2911 \\
& Streptomycin & 7913 & 1763 & 3047 \\
Exp. B & 5683 & 1374 & 2932 \\
& None & 4407 & 2433 & 2346 \\
& Neomycin & 6346 & 1122 & 1835 \\
& Neamine & 5087 & 2362 & 2186 \\
& Methylneo- & 4197 & 2368 & 2218 \\
& biosaminid & & & \\
& 2-Desoxy- & 4144 & 2341 & 2307 \\
& streptamine & & & \\
Exp. C & None & 3534 & 1896 & 2077 \\
& Neomycin & 6252 & 1155 & 1757 \\
& Puromycin & 3519 & 1720 & 2088 \\
& Clindamycin & 3573 & 1714 & 2262 \\
& Cocaine & 3486 & 1703 & 1937 \\
& Lidocaine & 3668 & 1993 & 2127 \\
& Putrescine & 3953 & 1979 & 2178 \\
& Spermidine & 4270 & 1866 & 2132 \\
& Spermine & 5170 & 1389 & 1966 \\
None & 6490 & 2473 & 3268 \\
Exp. D & 10,290 & 1068 & 2368 \\
& Neomycin & 6853 & 2537 & 3570 \\
L-Lysine & 6435 & 2397 & 3620 \\
& L-Lysine (1 mM) & 9644 & 2217 & 3548 \\
& Poly-L-lysine & 12,416 & 623 & 1711 \\
& Poly-L-lysine & & & \\
\hline & (1 mu) & & & \\
\hline
\end{tabular}

Incubations were performed as described in 'Methods' with $5 \mathrm{mM}-\mathrm{MgCl}_{2}$.

Exp. A: $1.1 \mathrm{mg}$ protein of nerve ending fraction. $14 \mu \mathrm{Ci}$ ${ }^{32}$ P-ATP

Exp. B and C: $1.3 \mathrm{mg}$ protein of nerve ending fraction. $8 \mu \mathrm{Ci}{ }^{32} \mathrm{P}$-ATP.

Exp. D: $1.3 \mathrm{mg}$ protein of nerve ending fraction. $12 \mu \mathrm{Ci}$ ${ }^{32} \mathrm{P}$-ATP.

Poly-L-lysine, average MW 3400 . Molarity in table is given as molarity with respect to lysine residues for comparison with the monomers. ' $1 \mathrm{mM}$ ' corresponds to 0.04 mM-polymer.

\section{Hydrolysis of polyphosphoinositides}

For the study of the enzymatic hydrolysis of polyphosphoinositides, lipids were labelled by $\left[\gamma^{32} \mathrm{P}\right] \mathrm{ATP}$ as described above. extracted and added to assays with the nerve ending fraction. Only little hydrolysis was observed when the conditions of the labelling studies (ATP omitted) were employed. In a medium more suitable for the assay of polyphosphoinositide phosphomonoesterases and phosphodiesterases (Sheltawy et al.. 1972; KeOlgh \& THOMPSON, 1972), the rate of hydrolysis was almost linear for $20 \mathrm{~min}$ during which about $30^{\circ} \%$ of both lipids were hydrolysed (Fig. 4). There was no nonenzymatic breakdown under these conditions. Neomycin was inhibitory at concentrations of $10^{-4} \mathrm{M}$ or higher (Fig. 5)

In these experiments where a known amount of ${ }^{32} \mathrm{P}$-polyphosphoinositides was added to the incubation medium, no influence of neomycin on the recovery could be detected (Fig. 5).

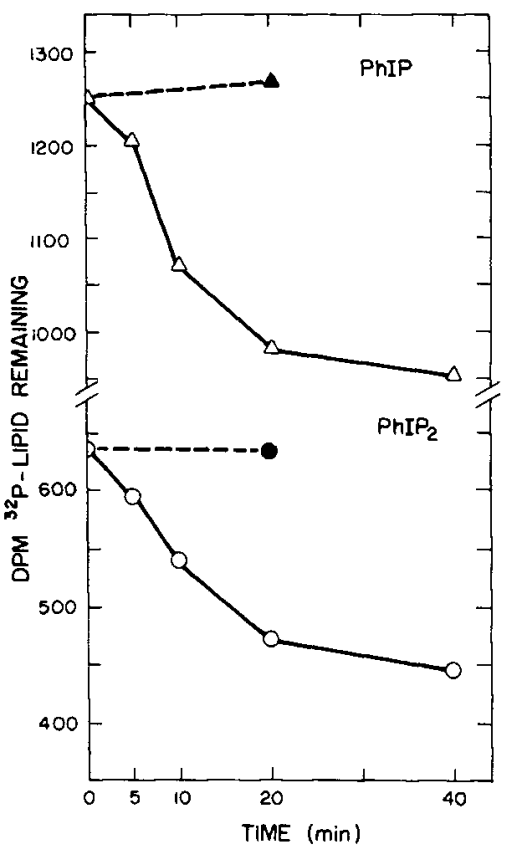

FIG. 4. Time course of hydrolysis of polyphosphoinositides. A nerve ending fraction (1.1 $\mathrm{mg}$ protein) was incubated with previously labelled lipids as described in 'Methods'. Closed symbol: incubation with bovine serum albumin substituting for nerve ending fraction.

\section{Drug/lipid interactions}

Low concentrations of neomycin increased the turbidity of buffered aqueous dispersions of polyphosphoinositides (Fig. 6). At a lipid concentration of

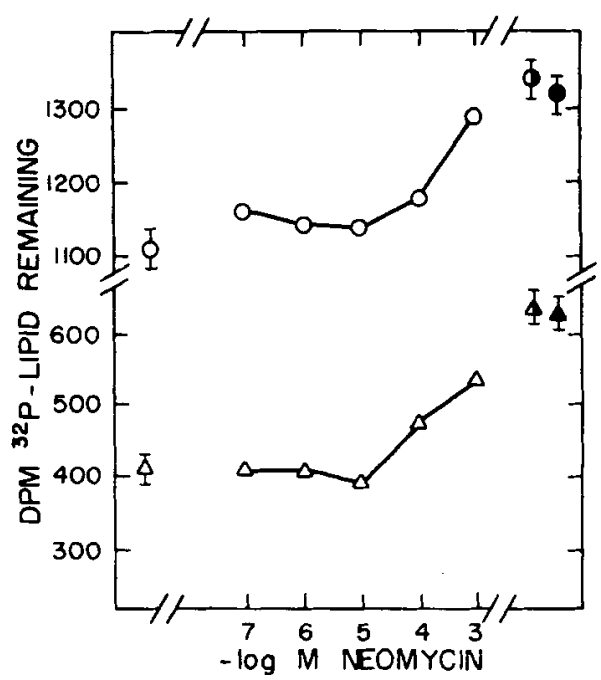

Fig. 5. Effect of neomycin concentration on hydrolysis of polyphosphoinositides. A nerve ending fraction $(1.1 \mathrm{mg}$ protein) was incubated with previously labelled lipids for $20 \mathrm{~min}$ as described in 'Methods'. O-O PhIP, $\triangle-\triangle$ $\mathrm{PhIP}_{2}$; Symbols at the left ordinate: control incubation without drug. Half closed symbols at the right ordinate: ${ }^{32}$ P-lipid present at the start of the incubation; fully closed symbols: same, but extraction in the presence of $10^{-3} \mathrm{M}$-neomycin. 
$0.4 \mathrm{~mm}$-lipid-phosphate, $40 \mu \mathrm{M}$-neomycin produced maximal turbidity. The same concentration of the drug decreased the $\mathrm{pH}$ of an unbuffered aqueous polyphosphoinositide suspension $(0.2 \mathrm{~mm}$-lipid-phosphate) from 6.1 to 5.6 indicating an ionic exchange between the hydrogen of the lipid phosphate and neomycin.

\section{DISCUSSION}

The rapid labelling of phosphatidylinositol phosphate and phosphatidylinositol diphosphate in brain subcellular fractions in vitro by the reactions (COLODZIN \& KENNEDY, 1965; KAI et al., 1968):

$$
\begin{aligned}
& \text { Phosphatidylinositol }+\left[\gamma^{32} \mathrm{P}\right] \mathrm{ATP} \rightarrow \\
& \text { phosphatidylinositol }\left[{ }^{32} \mathrm{P}\right] \text { phosphate }+ \text { ADP } \\
& \text { Phosphatidylinositol phosphate }+\left[\gamma^{32} \mathrm{P}\right] \text { ATP } \rightarrow \\
& \text { phosphatidylinositol }\left[{ }^{32} \mathrm{P}\right] \text { diphosphate }+ \text { ADP }
\end{aligned}
$$

makes this an easily accessible system for the study of polyphosphoinositide metabolism. In this study we see a pronounced stimulation of ${ }^{32} \mathrm{P}$-incorporation into phosphatidylinositol phosphate and a decrease of incorporation into phosphatidylinositol diphosphate in the presence of neomycin. Labelling of phosphatidate, the only other highly labelled lipid, remained largely unaffected at low drug concentrations.

The susceptibility to neomycin did not seem to be associated with a particular subcellular fraction. The nerve ending fraction was selected for further studies on the basis of its efficiency of ${ }^{32} \mathrm{P}$-incorporation into

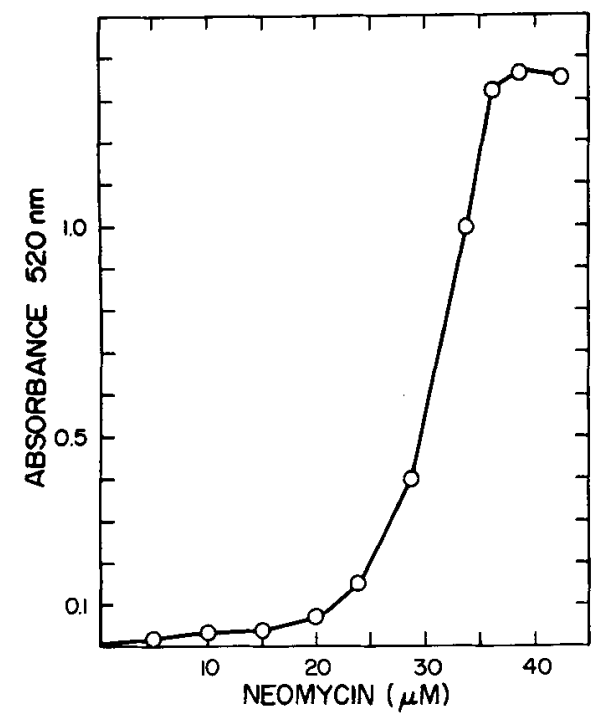

FIG. 6. Effect of neomycin on the turbidity of an aqueous dispersion of polyphosphoinositides. Neomycin (aliquots of a $0.5 \mathrm{~mm}$ solution) was added to a dispersion of polyphosphoinositides in $20 \mathrm{~mm}$ - $\mathrm{T}$ ris $\mathrm{Cl} \mathrm{pH} 7.4,(0.4 \mathrm{~mm}$ lipid phosphate) as described in 'Methods'. Turbidity was measured at $520 \mathrm{~nm}$, volume $1 \mathrm{ml}$. the lipids. The requirement for high magnesium concentrations for phosphatidylinositol and phosphatidylinositol phosphate kinase reactions is known (KAI et al., 1966, 1968), and was confirmed in our experiments. Low concentrations of $\mathrm{Mg}^{2+}$ appeared to favor a higher (percentage) stimulation of phosphatidylinositol phosphate labelling by neomycin. but the stimulatory effect on the diphosphate was inconsistent in a number of experiments. Five $\mathrm{mM}^{-} \mathrm{Mg}^{2+}$ promoted almost maximal labelling of phosphatidylinositol diphosphate and a pronounced and reproducible effect of the drug on both polyphosphoinositides. Variation of the $\mathrm{pH}$ of the incubation medium significantly changed the antibiotic action. With increasing $\mathrm{pH}$, basal labelling of phosphatidylinositol phosphate is only slightly affected while the stimulation by neomycin is reduced. At $\mathrm{pH} 9$, no drug effect is evident. Since the apparent $\mathrm{pK}$ of neomycin is approx. 8.2 (KOEPSELL \& FORD, 1958) this indicates that the cationic form of the antibiotic is the active species in changing the lipid labelling.

It appears unusual that labelling of phosphatidy. linositol phosphate and diphosphate are affected in opposite ways. A number of previous studies have indicated that both lipids show a similar response to drugs or experimental conditions that change their turnover (WHITE et al., 1974; SCHACHT \& AGRANOFF, 1972a, b; LLOYD et al., 1972). Since phosphatidylinositol kinase and phosphatidylinositol phosphate kinase are distinct enzymes, a differential action by neomycin is not surprising. Inhibition of the latter enzyme might explain all of the observed effects on ${ }^{32}$ P-incorporation. A stimulation of phosphatidylinositol diphosphate phosphomonesterase might also be considered to explain the incorporation studies, but this mechanism is contradicted by the inhibition of polyphosphoinositide breakdown evident in experiments in which neomycin was added to previously labelled lipids. Examination of the action of a number of other drugs suggests, however, a third mechanism. The neomycin effect is class-specific. It is shared by structurally-related antibiotics of the aminoglycoside group, but not by other antibacterial agents or local anesthetics. The latter are also known to interact with phospholipids. EICHBERG \& HAUSER (1974) reported a stimulation by cocaine and lidocaine of ${ }^{32} \mathrm{P}_{\mathrm{i}}$ incorporation into acidic phospholipids in the intact pineal gland. FeINSTEIN (1964) described the formation of ionic complexes between local anaesthetics and phospholipids. In this study, only polyamines produce changes in lipid labelling like those produced by neomycin. Poly-L-lysine has been reported to form insoluble mixed complexes with $\mathrm{Me}$ (II) ions and phosphatidylinositol diphosphate (FULLINGTON \& HeNDRICKSON, 1966) and we suggest a similar action for neomycin. The turbidity experiment confirms the formation of a complex between polyphosphoinositides and the drug. The displacement of $\mathrm{H}^{+}$from the polyphosphoinositides indicates that the complex is based on ionic interactions, which is supported by the fact 
that the neomycin cation is required for the effect on lipid labelling.

Our study then suggests that the binding of neomycin to the polyphosphoinositides renders these lipids unavailable as substrates for the phosphoesterases and for phosphatidylinositol kinase. This assumption of a complex formation between neomycin and the polyphosphoinositides is sufficient to explain the observed in vitro effects as well as the in vivo neomycin action on inner ear tissues as we have previously speculated (OrSUlakova et al.. 1976). Cellular toxicity of polycations including poly-Llysine is documented for the rat kidney (SELER, et al., 1975). Ototoxic effects of polycations have, to our knowledge, not been reported. Preliminary studies (Nuttall \& Schacht, unpublished) indicate that spermine as well as poly-L-lysine decrease the cochlear microphonic potential when administered by cochlear perfusion. Thus, the ototoxicity of neomycin may well be due to the polyamine character of the drug.

It should be expected that neomycin will also bind to other acidic phospholipids. This question still has to be examined, but this study indicates some preferential action on polyphosphoinositides at low drug concentrations. Moreover, our in vivo studies of neomycin toxicity in the inner ear (Orsulakova et al., 1976) and recently in the kidney (SCHIBECI \& SCHACHT, 1976) demonstrated a neomycin effect on the polyphosphoinositides but not on other lipids. Further investigations of drug/lipid interactions in artificial membranes (LoDHi et al., 1976) should help to elucidate this point. Knowledge of the specificity of the neomycin action and of its physiological effects in vivo may contribute to our understanding of the functional significance of the polyphosphoinositides.

Acknowledgements - This work was supported by NIHNIEHS Contract No. NO1-ES-2-2110, by NIH Program Project Grant No. NS 05785 and by a grant from the John A. Hartford Foundation. Inc.

\section{REFERENCES}

Ames B. N. \& Dubin D. T. (1960) J. biol. Chem. 235. $769-775$.

Colodzin M. \& Kennedy E. P. (1965) J. biol. Chent. 240, $3771-3780$.
Eichrerg J. \& Halser G. (1974) Biochem. Biophys. Res. Commun. 60. 1461-1467.

Eichberg J., Shein H. M., Schwartz M. \& Hauser G. (1973) J. biol. Chem. 248, 3615-3622.

Feinstein M. B. (1964) J. Gen. Physiol. 48, 357-374.

Fullington J. G. \& Hendrickson H. S. (1966) J. biol. Chem. 241. 4098-4100.

Hauser G. \& Eichberg J. (1973) Biochim. biophys. Acta 326. $201-209$.

Hawkins J. E., JR. (1970) in Biochemical Mechanisms in Hearing and Deafness (PAPARELlA M. M., ed.) pp. 323-339. Thomas, Springfield, IL.

Hendrickson H. S. \& Ballou C. E. (1964) J. biol. Chem. 239, 1369-1373.

Huang K. P. (1970) Analyt. Biochem. 38, 383-388.

Kai M., White G. L. \& Hawthorne J. N. (1966) Biochem. J. 101. 328-337.

Kai M. Salway J. G. \& Hawthorne J. N. (1968) Biochem. J. 106, 791-801.

KeOUGh K. M. W. \& Thompson W. (1972) Biochim. biophy's. Acta 270, 324-336.

KOEPSELl H. J. \& FORD J. H. (1958) in Neomycin (WAKSMAN S. A., ed.) pp. 60-72. Williams \& Wilkins, Baltimore. MD.

Lloyd J. V., Nishizawa E. E., Haldar J. \& Mustard J. F. (1972) Br. J. Haematol. 23, 571-585.

Lodhi S., Weiner N. D. \& Schacht J. (1976) Biochim. Biophys. Acta. 426, 781-785.

Lowry O. H., Rosebrough N. J., FARR A. L. \& RANDALl R. J. (1951) J. biol. chem. 193, 265-275.

Michell R. H. (1975) Biochim. biophys. Acta 415, 81-147.

Nuttall A. L., Marques D. M., Stockhorst E. \& Schacht J. (1975) J. Acoust. Soc. Amer. 57, S 60.

Orsulakova A., Stockhorst E. \& Schacht J. (1976) $J$. Neurochem. 26, 285-290.

Pittinger C. \& Adamson R. (1972) Ann. Rev. Pharmac. 12. $169-184$.

Schacht J. \& Agranoff B. W. (1972a) J. biol. Chem. 247, 771-777.

SCHaCht J. \& AGRANOFF B. W. (1972b) J. Neurochem. 19, 1417-1421.

ScHACHT J. (1974) Annls, Otolar. 83, 613-618.

SChendel P. F. \& Wells R. D. (1973) J. biol. Chem. 248, 8319-8321.

Schibecl A. \& Schacht J. (1976) Fedn Proc. Fedn Am. Socs exp. Biol. 35, 1725.

Seller M. W., Venkatachalam M. A. \& Cotran R. S. (1975) Science 189, 390-393.

Sheltawy A., Brammer M. \& Borrill D. (1972) Biochem. J. 128. 579-586.

White G. L., Schellhase H. U. \& Hawthorne J. N. (1974) J. Neurochem. 22, 149-158. 